\title{
The Engagement Model, Transition Processes and a New Definition of Health
} Jan Sitvast*

University of Applied Sciences, Hogeschool Utrecht (HU), Heidelberglaan 7, Utrecht, The Netherlands

*Corresponding author: Jan Sitvast, University of Applied Sciences, Hogeschool Utrecht (HU), Heidelberglaan 7, Utrecht, The Netherlands, E-mail: jan.sitvast@hu.nl Received date: Apr 27, 2016; Accepted date: June 10, 2016; Published date: June 13, 2016

Copyright: ( 2016 Sitvast J. This is an open-access article distributed under the terms of the Creative Commons Attribution License, which permits unrestricted use, distribution, and reproduction in any medium, provided the original author and source are credited

\begin{abstract}
This article is about a new definition of health and how this relates to transition processes. It focuses on the practical translation of the new concepts into challenges for mental health nurses. To that aim the Engagement Model is examined and operationalized. We did so as nurse researcher and lecturer involved in training nurse practitioners.
\end{abstract}

Keywords: Engagement model; Transition process; Health

\section{Introduction}

The Dutch professional profile for nurses [1] has adopted the new concept of health as presented by Huber et al. Health is the capacity of people to adapt and direct their coping with adversities of life against the background of physical, emotional and social challenges. Being healthy means to be able to adapt to disruptions, show resilience and maintain a balance of rediscover this balance physically, mentally and socially [2]. This is considered as positive health. We do not any longer follow the concept of health as a state of complete physical, mental and social well-being as this concept (formulated by the WHO in 1948) implicated that many people must be classified as ill even where they coped with their disease very well and they themselves would not describe themselves as ill (Table 1).

In the professional profile, the promotion of health is seen as the core of nursing [1]. Seen in the light of the new definition of health this means:

\begin{tabular}{|l|l|}
\hline \multicolumn{2}{|l|}{ Aims, intervention and results of nursing } \\
\hline Aims & $\begin{array}{l}\text { The promotion of health, recovery, growth and development and } \\
\text { the prevention of illness, afflictions and impairments. }\end{array}$ \\
\hline Intervention & $\begin{array}{l}\text { The strengthening of people's ability to self-manage as much as } \\
\text { possible. } \\
\text { Empowering people and helping them with attaining, } \\
\text { maintaining or acquiring (or re-acquiring) their independence. } \\
\text { Assessing the need for nursing care; therapeutic interventions } \\
\text { and personal care; information, education, advice and } \\
\text { advocacy; physical, emotional and spiritual support. }\end{array}$ \\
\hline Results & $\begin{array}{l}\text { Strengthened self-management, better quality of life. The } \\
\text { prevention of loss, the upkeep or improvement of aspects of } \\
\text { daily functioning. }\end{array}$ \\
\hline
\end{tabular}

Table 1: Aims, intervention and results of actions by nurses [1].

Connecting 'being self-directed' with health and self-management we think that the process of giving meaning to life experiences (among them life's adversities: for instance chronic illnesses) may play a central role in all domains of health [1]. Huber et al. [2] distinguishes 6 domains of health, namely: the physical, the mental, the spiritual/ existential and the social dimension, quality of life and general daily skills. As patients responded that "Positive health concerns life in all its aspects". 'Positive health' can be characterised by diffuse demarcation lines between care and the social domain. We expect that by supporting people in all aspects of positive health, their resilience and capacity for self-management will be strengthened and that quality of life will improve [3]. In mental health care the taking of one's life in one's own hands again, (re)finding a positive identity and starting to live according one's values, is often called: recovery.

In order to achieve these results, the following issues are important:

\section{Awareness and education;}

2. Establishing what patients really think is of value to them;

3. Self-management: an attitude that matches a person's conduct to the values he/she strives after. In this way, things of value will be protected [3] and it will help patients to harness their powers of resilience.

Where this is true in general with most patients, it becomes urgent on so called transition moments. Transition moments as defined by Tomlinson [4] are: "a movement from one state to another that is accompanied by change in roles, relationships, or patterns of behavior". Transition moments are characterised by high levels of complexity as patients negotiate turning points in the life course or in the career which necessitates reorienting oneself to one's past, the present situation and the future still to come. Meaning must be found in a new situation, losses must be integrated in one's life, a new balance (re-) established and a new identity may even be desired. According to Meleis et al. [5] it is the task of nurses to support patients during transition moments and pay attention to essential aspects inherent to the experience of transition: awareness, engagement, time span, the relevance of critical points and events and experiencing changes and differences. Dealing with these aspects in a positive way may contribute to vigour and the strength to move on to a new phase in life.

The role of nurses in supporting this process becomes more and more important as we move into an era of personalised health care with treatment 'tailored' to the specific individual needs of the patient. For mental health care the Dutch government made this one of the two research themes for which funding will be granted. However, in general health care this focus will increasingly become the norm [6].

Searching for an approach that health care professionals can use to deliver more personalised care that addresses the need for awareness 
and education; living according one's values and; increased selfmanagement, we found the Engagement Model.

The Engagement model is an approach in mental health care that matches best the idea of strengthening resilience, in order to reduce rates of seclusion and restraint [7]. The Engagement model teaches caregivers how to engage with clients in such a way that patients experience warmth, trust and hospitality. This furthers an active involvement between clients, family and caregivers.

The Engagement Model is based on the exemplary work of Murphy and Bennington-Davies [7] who made 'engagement' the central element of their reform in Salem Hospital in Salem, Oregon and elsewhere in the United States, where they succeeded in reducing the rates of seclusion and restraint. Also Huckshorn's six core strategies for reducing seclusion and restraint [8] inspired us as she also incorporated the idea of engagement. In the Netherlands it was the increasing interest in implementing comfort rooms that led us to reflect on the engagement idea that was connected with it $[9,10]$. Another strong impulse came from the best practice 'The First Five Minutes' that was developed in Amsterdam on acute wards of a psychiatric hospital and that focuses on ways and procedures of how to approach new patients during the first hours (days) of their stay at the hospital [11]. These ways and procedures aim to create an atmosphere of hospitability and cooperation and are thus closely related to the Engagement Model. This best practice has been implemented in a number of mental health institutes in the Netherlands [12]. On the level of nationwide policy it is important to mention that in $2010 \mathrm{GGZ}$ Nederland, the inter-branch organization of mental health care organizations in the Netherlands provided recognition of the principles behind the Engagement model in the vision document 'Intensive Care in de GGZ. Op weg naar veldnormen'. This document offered field norms and practical strategies that can be used to apply the Engagement model in practice.

What does the Engagement Model look like in practice? Let us first state its main principles:

1. Offering a safe and hospitable environment.

2. Giving attention to and understanding the impact of stressful life-events (Trauma-informed care).

3. An approach and way of working that gives priority to collaboration with the client. The contact must be based on equivalence and the belief of recovery.

4. Utilising experiential expertise.

5. Inspiring leadership.

6. Community/Social Standards.

7. Risk Management.

The aim is to connect with the lived experiences of the client and his relatives in a proactive way. It does so by stimulating teams to make use of the experiential expertise of clients and the active involvement of the family recognizing that they form partners in a treatment triad. Patient experiences of traumatization and experiences with earlier admissions in hospital in the past are given due attention. The same applies to the fact that the disruption caused by a situation of crisis may be responsible for fending off and resisting help and care offered by caregivers. When this results in problem behavior, then it will be considered as a chance and not a threat for establishing a cooperative relationship. Caregivers will have an understanding attitude for the client's reactions and not stigmatize them as 'deranged' or as 'sick'. Instead they will invite the client to cope with his problems in another way. The team of caregivers must radiate a message of hope that overcoming crisis is possible and that there are possibilities of personal growth and development [13].

The Engagement approach focuses on making contact with clients. Making contact with clients in an engaged way aims at building a therapeutic alliance. This is done by nurses responding to the feelings and experiences of their clients and family in a proactive way. Why is this so important? Most clients will be admitted in a crisis situation. This will predispose them to see the ward environment as threatening. Negative experiences from the past will be likely to be relived and may trigger a strong defensive response that through interaction with staff may escalate into aggression and agitation that is then often met with measurements of constraint and seclusion. To prevent such an escalation it is important that clients when admitted to a crisis ward experience nurses as trustworthy. Nurses must transmit the message that they will treat clients with respect, that they are welcome and that they will be listened to. How this message is communicated depends just as much on what is been said as on attitude and non-verbal language. Do nurses have a posture of calmness and safety? Do they emphasize that the ward is a non-violent environment; do they carry an atmosphere of hope? If so patients do not have to spend energy in warding off and resisting threats they may perceive. Instead of activating existing learned ways of coping, ways that are often reenactments of responses to earlier traumatic experiences, an engaged approach stimulates patients to try new, more helpful ways of adaptation.

\section{Core concepts of the Engagement Model}

The core concepts of the Engagement model are: warm care, comfort, resilience and therapeutic alliance. By offering warm care, caregivers facilitate the clients to feel safe and comfortable. By feeling safe and comfortable clients will more easily be able to use their resilience to recover from a crisis. Caregivers will then have more access to support their clients with advice. A therapeutic alliance between clients and caregivers can be struck.

\section{Warm care}

Warm care is a form of caring that prioritizes hospitality and a person-focused commitment from a holistic perspective that does not reduce the client to his being a patient but encompasses all dimensions of being in the world as a bio-psychosocial and spiritual identity. It is oriented towards hearing a person's narrative and aims at reducing stress and establishing a safe and trusted environment (Table 2). Skills that caregivers can use to give their clients warm care are:

Being hospitable

Being reflective

Being responsive

Presenting: being present as an authentic person, not only as professional

Being involved and committed ('engagement')

Table 2: Warm care.

\section{Comfort}

Comfort is present in any situation where clients feel that they are safe and that they are invited to realise their potential for functioning 
Page 3 of 4

on a higher level of growth and development. This is the difference between just an ordinary ward environment and a healing environment [13]. Comfort is about how a space looks in its physical material aspects, concerning architecture, decoration and the functional organization. There is comfort when in situations of rising tensions and agitation one can use stress reducing means such as a comfort room [14]. If seclusion is nevertheless necessary then it must be guided (no solitary confinement) and the seclusion room must be equipped with relaxation techniques e.g. projection of calming and soothing landscapes on its walls (Figure 1); aroma therapy; music that sets one at ease; a relaxation chair. The ward environment is nonviolent. Aggression is not tolerated. The team's message is that there is hope to overcome crisis and that one can grow and develop. Comfort is more than a physical environment consideration, because it refers also to interaction aspects. Caregivers may be expected to have a thorough knowledge of trauma-related behaviour. Problematic behaviour is confronted with an understanding attitude as a way of coping that was learned from earlier situations, but now is not useful anymore. It is not necessarily seen as symptomatic for mental illness.

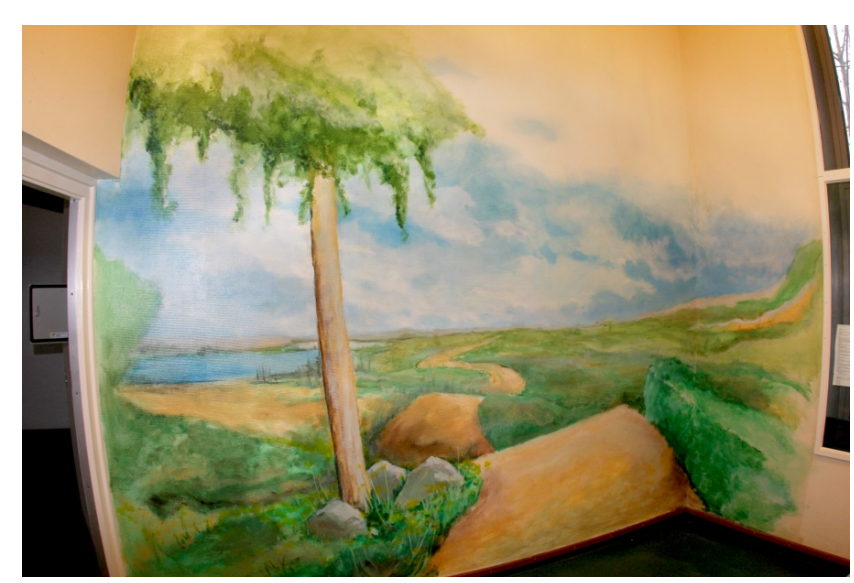

Figure 1: Seclusion room with landscape painted on the wall.

\begin{tabular}{|l|}
\hline Aspects of 'comfort' \\
\hline A safe and non-violent environment that welcomes newcomers \\
\hline Inviting to learn and grow \\
\hline Offering means for stress reduction \\
\hline Breathing hope \\
\hline $\begin{array}{l}\text { 'Difficult' trauma-related behavior is recognized and distinguished from } \\
\text { psychiatric symptoms, acknowledging that behavior may have been functional in } \\
\text { the past, but today stands in the way of maintaining meaningful relationships } \\
\text { with others. }\end{array}$ \\
\hline
\end{tabular}

Table 3: Aspect of Comfort.

Caregivers' responses aim to make clients realise that his behaviour, even where it was functional to survive in the past, may not serve this goal today and may be conflicting with his present values and norms. Caregivers may have as their goal to confront a client with his problematic behavior, but they will not use confrontation as a means, except in certain liminal situations of unacceptable behavior (Table 3).

\section{Resilience}

Most people have a natural resilience that helps them to transform and overcome a situation of hardship and crisis. This power of resilience depends on disposition, talents and skills, but also on how an individual has been embedded in a support system, his self-image and whether he thinks that a situation can be influenced (Table 4).

\begin{tabular}{|l|}
\hline Resilience depends on \\
\hline Individual talents/skills \\
\hline Self-image \\
\hline Cognitions on choices and fate (how much influence one has on one's own life) \\
\hline Situational factors \\
\hline
\end{tabular}

Table 4: Resilience.

\section{Therapeutic alliance}

In a therapeutic alliance the nurse fulfills the role of travel companion. As a travel companion the nurse can give advice, but preferably not unasked for or given from a position of having expert knowledge. That would distance the patient from the nurse and estrange the nurse from the role of travel companion. Nurses and other caregivers should realize that they cannot take over the work of directing one's own life. It is best is to potentialise someone's own powers of resilience. This means that caregivers use appropriate conversational techniques applying narrative interventions, exploring questioning and motivational interviewing (Table 5).

\section{Building a therapeutic alliance}

Avoid resistance/don't use confrontation as intervention style where this can be avoided

Convince, don't argue

Help someone to get a better insight in his own situation

Avoid speaking from a position of knowing better

Stimulate trust in someone's own strengths

Table 5: Therapeutic Alliance.

\section{Skills and architectural adaptations}

There are material and immaterial conditions that must be met to realize warm care, comfort, a focus on resilience and a therapeutic alliance. Think of functional adaptations of ward environments that could create an atmosphere of hospitability and warmth, but could also work as a mechanism to reduce stress (e.g. comfort rooms, retreats). Then we have the demands of training staff in new knowledge and skills. We offer some suggestions on how to organise this below.

Hospitality: Invite managers from hotels to train staff in how to be a host/hostess.

Safe and welcoming environment: adapt procedures and guidelines on how to communicate with patients.

Realisation: Have experiential experts examine the ward from the perspective of patients and screen all rooms on aspects of safety and creating a friendly atmosphere. Check if written and verbal 
Page 4 of 4

information is sufficiently transparent. Study the principles of the 'healing environment' and how to apply them in your hospital. Connect with your national Planetree organization. Organize benchmarking visits to other hospitals who have already realized a 'healing environment'.

Resilience: How to address someone's powers of resilience and strengthen them?

Health care professionals should strengthen the self-efficacy of clients and elicit from them self- motivating messages by using Motivational Interviewing techniques. They can stimulate patients to connect with their long term values in life and become aware of the strengths they can use when confronting the challenge of putting their lives in order and start living 'a valued life. Care professionals could for instance apply techniques such as the Values Compass from Acceptance and Commitment Therapy [15] and use creative interventions such as Hermeneutic Photography [16,17] in order to help patients to (re-)discover their own strengths and values and use them 'to lift a life up from the shackles of illness' [18].

\section{Opportunities and challenges}

The main principles of the Engagement Model offer an outline for (re-)organizing mental health care in line with the new definition of health. These principles can be used as performance indicators. What is needed then is an operationalization in smart formulated targets and the development of a scoring instrument to measure the degree of fidelity to the model during implementation. We (the author) intend to report on this process of operationalization and implementation in a mental health institute in a follow-up study. In this follow-up study we will also report on practical adaptations that were carried though during implementation. One of the risks of the Engagement Model is that it combines so many strands (organizational, attitudinal, educational (skills training)) and it may therefore be tempting for management to focus on short-term successes, for instance making some adaptations in decorating the ward in order to give it a more welcoming look and ignoring the more painstaking processes of changes of attitudes and skills. We think that inspiring leadership is necessary here and that nurse practitioners may play an important role here. We expect Master of Advanced Nursing Practitioners courses at Universities of Applied Sciences to take the lead in preparing students for this role [19-21]. This will also be discussed in our follow-up article.

\section{Conclusion}

The operationalization of the Engagement Model may help nurses to translate the new concept of health into daily care for patients when they support them in their transition from being overwhelmed by the impact of illness to taking the lead again in directing their lives and coping with the consequences of illness. We focused on mental health care, but we consider a psychiatric crisis as one of these transition moments in life which may not be so different from other transition moments in life. We think that the Engagement Model might offer a point of departure for the study of transition and what this means for the praxis of nursing in a broad sense, including also in the context of somatic diseases and conditions.

\section{Acknowledgement}

We thank Dr. Oonagh Meade for her critical reading and check of correct English.

\section{References}

1. Schuurmans M (2012) Policy report In: Verpleegkundigen and Verzorgenden 2020 (V\&V2020). VenVN, Utrecht, The Netherlands.

2. Huber M, Knottnerus JA, Green L, Van der Horst H, Jadad AR, et al. (2011) How should we define health? BMJ 343: d4163.

3. Huber M, Staps S (2016) Zelfmanagement voor gezondheid en leefomgeving: tijd voor een nieuwe aanpak -position paper. Louis Bolk Instituut and Institute for Positive Health, Wageningen, The Netherlands.

4. Marineau M (2005) Health/Illness Transition and Telehealth: A concept analysis using the evolutionary method. Nurs Forum 40: 96-106.

5. Meleis AI, Sawyer L Im EO, Messias DK, Schumacher K (2000) Experiencing transitions: an emerging middle-range theory. ANS Adv Nurs Sci 23: 12-28.

6. Vlek H, Driessen S, Hassink L (2014) Persoonsgerichte Zorg. White paper. Kenniscentrum Vilans, Utrecht, The Netherlands.

7. Murphy T, Bennington-Davies M (2005) Restraint And Seclusion: The Model for eliminating use in healthcare, American Psychiatric Publishing, Arlington, Virginia, USA.

8. Huckshorn KA (2005) Planning Tool. In: Six core strategies to reducing seclusion and restraint use. National Association of State Mental Health Program, Alexandria, Virginia.

9. De Veen RCA, Vruwink FJ, Voskes Y, Mulder CL, Noorthoorn EO (2009) Het Comfortroom-project Mediant. Ervaringen en uitkomsten. MGv 64: $551-560$.

10. Souverijn A (2009) Een comfortroom voor psychiatrische patienten. Tijdschrift voor Ziekenverzorging 11: 62-65.

11. Stringer B, Welleman R, Berkheij E, Keppel P, Kleve J (2008) De eerste vijf minuten: het halve werk. Eindverslag project 'Vermindering dwangtoepassingen. Het voorkomen en bekorten van separaties begint bij elke eerste vijf minuten van een nieuw contact, GGZIngeest, Amsterdam.

12. Voskes Y, Theunissen J, Widdershoven G (2011) Best Practices rondom dwangreductie in de Geestelijke Gezondheidszorg. Een inventariserend onderzoek naar best practices bij de reductie van dwang. VU Medisch Centrum/ GGZNederland, Amsterdam.

13. Bloom S (1997) Creating sanctuary: towards the evolution of sane societies. Routledge, New York.

14. Cummings KC, Grandfield SA, Coldwell CM (2010) Caring with comfort rooms. Reducing seclusion and restraint use in psychiatric facilities. J Psychosoc Nurs Ment Health Serv 48: 26-30.

15. Hayes SC, Luoma JB, Bond FW, Masuda A, Lillis J (2006) Acceptance and commitment therapy: Model, processes and outcomes. Behav Res Ther 44: $1-25$.

16. Sitvast J, Abma TA, Lendemeijer HHGM, Widdershoven GAM (2008) Photo stories, Ricoeur, and Experiences from Practice: a Hermeneutic Dialogue. ANS Adv Nurs Sci 31: 268-279.

17. Sitvast J (2014) Hermeneutic Photography: An innovative intervention in psychiatric rehabilitation founded on concepts from Ricoeur. Psy J Nurs 5: $17-24$

18. Grijpdonck M (1999) Het leven boven de ziekte uittillen. In: Pool A, en J Lambregts (edn.) Verpleegkundige zorgverlening aan chronisch zieken. Lemma Publisher, Utrecht.

19. Huber M, Van Vliet M, Giezenberg M, Winkens B, Dagnelie PC, et al (2016) Towards a 'patient-centred' operationalisation of the new dynamic concept of health: a mixed methods study. BMJ Open 5:e010091.

20. Meymandi A (2009) Soothing while secluding. In: I Needham, P Callaghan, T Palmstierna, H Nijman N Oud (2009) Proceedings of the 6th European Congress on Violence in Clinical Psychiatry, Kavanah Publisher, Dwingeloo, The Netherlands, pp. 32-34.

21. Sitvast J (2013) Self-management and the representation of reality in photo stories. ANS Adv Nurs Sci 36: 1-15. 